\title{
Intercultural Competence Cultivating in Higher Vocational Education from the General Education Perspective
}

\author{
Sheng-Hua ZHANG \\ General Platform Department, Beijing Information Technology College \\ Beijing Information Technology College, 100016 \\ Beijing, People's Republic of China \\ zhangsh@bitc.edu.cn \\ *Corresponding author
}

Keywords: General education, Intercultural competence

\begin{abstract}
Intercultural competence (IC) is one of the top important competences in modern general education. However, in higher vocational education, the emphasis on IC is weak; the research is not deep and wide enough, and the IC cultivating system is still lacking. The gap between the expectation of intercultural competence of the students and the reality of higher vocational education is wide. To narrow this gap, this study tries to discuss the current situation of IC cultivating in higher vocational colleges and how to construct the IC cultivating system from the general education perspective.
\end{abstract}

\section{Introduction}

With the increasing globalization, the interaction between people from different cultural background becomes more and more frequent. Thus, intercultural competence is no longer a skill confined only to diplomats. It turns into an important part of modern general education. On November 4th 2015, UNESCO formally launched The Education 2030 Framework for Action (FFA) [1]. It advocates the promotion of a culture of peace and non-violence, global citizenship and appreciation of cultural diversity and of culture's contribution to sustainable development. In the field of higher education, plenty of scholars, universities and colleges worldwide consider IC as the important part in modern general education.

Facing the chances and challenges in the new era, China proposed the concept of "building a human community with shared destiny" and the Belt and Road Initiative. This mirrors China's commitment to the rest of the world and brings up a new requirement for intercultural communication.

Meanwhile, vocational internationalization deepens quickly. The interactions between students, scholars, teachers, experts from different countries and different cultures become more and more frequent. According to the Higher Vocational Education Yearbook 2017, in 2016, about 100 higher vocational colleges adopts about 283 international education or industry standards [2]. Some Chinese higher vocational colleges has opened branches in other countries. By studying abroad, attending international contest or exchange programs, etc., more and more students in higher vocational colleges have chances to interact with people from other countries and cultures.

Thus, cultivating IC of the students becomes the important part of general education in Chinese higher vocational education.

\section{General Education and Intercultural Competence}

\section{The Significance of Intercultural Competence in General Education}

General education evolves from the liberal arts education in ancient Greece. It was based on the medieval concept. The liberal arts referred to the seven arts: the arithmetic, geometry, astronomy, music, grammar, logic and rhetoric. Due to the impact of industrial revolution, there was a heat 
discussion over general education in early $19^{\text {th }}$ century. The curriculum based on the original seven liberal arts such as classical languages, literature, history, religion, mathematics and basic sciences met great challenges [3]. Some scholars argued that the liberal arts should be replaced by practical courses. In 1827 the famous The Yale Report was issued, which greatly influenced American higher education. In 1828, A. S. Packard first used the term "general education” in his essay published on North American Review.

In the following years, general education evolves according to the development of the society. Universities, colleges and organizations put forward and implement their ideas about general education. The following chart shows the core areas in modern general education in typical schools or organizations.

Table 1 Core Areas in Modern General Education

\begin{tabular}{|c|c|c|c|}
\hline No. & $\begin{array}{c}\text { Universities/Colleg } \\
\text { es/Organizations }\end{array}$ & Core Areas & Remark \\
\hline 1 & Harvard University & $\begin{array}{l}\text { Eight Areas: Aesthetic and Interpretive Understanding, Culture } \\
\text { and Belief, Empirical Reasoning, Ethical Reasoning, Science of } \\
\text { Living Systems, Science of the Physical Universe, Societies of the } \\
\text { World, The United States in the World [4] }\end{array}$ & $\begin{array}{l}\text { Report of } \\
\text { the Task } \\
\text { Force on } \\
\text { General } \\
\text { Education, } \\
2007\end{array}$ \\
\hline 2 & $\begin{array}{ll}\text { Northern } & \text { Illinois } \\
\text { University } & \end{array}$ & $\begin{array}{l}\text { Seven Pathways: Creativity, Innovation, and Change; Global } \\
\text { Connections; Health and Wellness; Learning; Origins and } \\
\text { Influences; Social Justice and Diversity; and Sustainability [5] }\end{array}$ & $\begin{array}{l}\text { Progressiv } \\
\text { e Learning } \\
\text { in } \\
\text { Undergrad } \\
\text { uate } \\
\text { Studies, } \\
2016\end{array}$ \\
\hline 3 & $\begin{array}{l}\text { National University } \\
\text { of Singapore }\end{array}$ & $\begin{array}{l}\text { Five main curriculum pillars: Singapore Studies; Human Cultures; } \\
\text { Quantitative Reasoning; Thinking and Expression and the fifth } \\
\text { Pillar [6] }\end{array}$ & 2012 \\
\hline 4 & United Nations & $\begin{array}{l}\text { UN Core Values: Integrity; Professionalism; Respect for diversity } \\
\text { [7] }\end{array}$ & $\begin{array}{l}\text { Up to the } \\
\text { present }\end{array}$ \\
\hline 5 & Fudan University & $\begin{array}{l}\text { Six broad areas of study: humanities and cultural heritage, } \\
\text { philosophy and critical thinking, cultural dialogue and world } \\
\text { vision, scientific spirit and scientific exploration, ecology and } \\
\text { biological conservation, artistic creativity and aesthetic } \\
\text { experience [8] }\end{array}$ & 2012 \\
\hline 6 & Peking University & $\begin{array}{l}\text { Five basic fields: Mathematics and Natural Science, Social } \\
\text { Science, } \\
\text { Philosophy and Psychology, History as well as Linguistics, } \\
\text { Literature and Art [9] }\end{array}$ & $\begin{array}{l}\text { Yuanpei } \\
\text { Program } \\
2008\end{array}$ \\
\hline
\end{tabular}

The above Table 1 shows that in order to help the students to face the changing environment and the challenges in $21^{\text {st }}$ century, universities or organizations around the world adjust the goals, the contents, and the approaches of general education. Among the core areas, culture has been given great emphasis. In today's increasingly diverse societies, people become more connected with each other than ever before. We have more and more opportunities to cooperate, communicate and even conflict with the others from different cultural background. It is of great importance for the interaction between people from different cultures and meaningful for the world peace and development. Thus, we can arrive at the coulclusion that higher vocational education should cultivate the intercultural competence of the students and help the students to adapt to the cultural diversity in aspects of knowledge, skill and values, etc.

\section{The Key Factors of Intercultural Competence}

According Michael Byram, five factors comprises the intercultural competence, that is attitude, knowledge, skills of interpreting and relating, skills of discovery and interaction and critical cultural awareness/political education [11]. Among the five factors, knowledge and attitude are preconditions. 
The intercultural competence also include two skills. The first is the ability to interpret a document or event from another culture, to explain it and relate it to documents or events from one's own. The second is the ability to acquire new knowledge of a culture and cultural practices and to apply the knowledge, attitudes and skill in a real interaction. Sun Youzhong holds that intercultural competence means respecting the diversity of cultures, and have the intercultural empathy and critical cultural awareness; grasping the intercultural research theories and methods; being familiar with the history and current situation of the object country, understanding the basis characteristics and differences and similarities between Chinese and other cultures; being able to explain and evaluate different cultural phenomenon, context or products; being able to conduct intercultural communication effectively; being able to help people from different cultures communicate effectively[12]. For higher vocational education, the knowledge of self-culture and other-culture, the attitude of treating self-culture and other culture positively, and the critical cultural awareness are the three key factors.

\section{The Current Situation about Intercultural Competence Cultivating in Higher Vocational Education in China}

\section{The Relevant Policies are not Enough and Clear}

In July 2010, China announced the Outline of China's National Plan for Medium and Long-term Education Reform and Development (2010-2020). In this plan, the higher education was asked to further the international understanding education, to help the students strengthen their understanding of different countries and different cultures, to foster the intercultural interaction, and try to cultivate the modern talents who have the international vision, be familiar with the international practices and can be actively involved in the international affairs and competitions. This is an important instructional policy. Yet, how to achieve the goals? We can hardly find other relevant polices or curriculum which can support this plan.

\section{The Emphasis on Intercultural Competence in General Education is not Enough}

In China, general education in higher vocational education lagged behind common higher education. One of the important mission for higher vocational education is to prepare the students for the specific profession. In higher vocational education, too much attention and emphasis has been put on the major education and the attention on general education is not enough. In fact, in vocational education, general education and professional education are complementary. They should develop equally and evenly, which will help the students become a qualified citizen. As far as intercultural competence is concerned, it is not treated as an important part in general education and the cultivating pathways and approaches are still lacking.

\section{The Scope of Intercultural Competence Research is not Broad Enough}

Research made by Hu Wenzhong in 2010 shows that China' s intercultural communication has leaned heavily towards foreign language education and the scope of research has not been broad enough[10]. Most of those involved in intercultural competence research are foreign language teachers and the scope of research is confined to cultivating intercultural communication competence in foreign language teaching (especially in English teaching).

Choosing "intercultural competence" as the keyword in China National Knowledge Internet (CNKI), we can get 790 papers issued from 1971 to 2017. 61.52\% of the papers are concerned with foreign language or foreign language teaching, $10.89 \%$ of the papers are concerned with Chinese language and $8.73 \%$ are concerned with higher education [13]. Among the top ten cited papers, 8 papers are related with foreign language teaching. The most co-cited keywords are: intercultural communication competence, intercultural communication, intercultural, foreign language teaching and cultural ability.

These findings shows that the research about intercultural competence are mostly confined to foreign language teachers and foreign language teaching. The focus is on how to cultivate the 
intercultural competence in foreign language classes. Yet, foreign language classes should not take the entire responsibility of cultivating intercultural competence.

\section{The Intercultural Competence Cultivating System is Still Lacking}

Due to the inadequate understanding of intercultural competence and the vague teaching objectives, the intercultural competence cultivating system is still lacking. The relevant courses scatters in different fields. There is no strong connection between these courses. Let's take the courses related to intercultural competence in Beijing Information Technology College (BITC) as an example. BITC is a key higher vocational college and the curriculum is typical. For the compulsory courses concerned with intercultural competence are English, Cultivation of Ethics and Fundamentals of Law, Mao Zedong Thought and the theory of building socialism with Chinese characters, workplace communication. For elective course concerned with intercultural competence are Chinese language literature, Chinese Classical Literature Appreciation, Foreign Classical Literature Appreciation, Chinese traditional culture, Chinse general history, world history, etc. Students are not required to choose the elective courses evenly and they can choose the elective courses according to their interest. The compulsory courses and the elective courses are conducted independently and without a clear domain. All these result in the irrelevance and overlap of the courses.

\section{The Understanding of Intercultural Competence is not Deep and Clear}

The teachers who carry out the IC related courses do not have a clear and deep understanding of the components and the pathways of intercultural competence. In the related courses, teachers introduce the different cultures to the students, but they ignore how to cultivate the critical cultural awareness. Sometimes students are told to "do as the romans do". As a result, when interacting with people from different cultural background, some students do not know how to interact and some students lose their cultural identity.

\section{The Suggestions for Constructing Intercultural Competence Cultivating System in Higher Vocational Education}

In order to cope with the current problems and construct an IC cultivating system, some suggestions are listed here.

\section{Place more Emphasis on Designing the Intercultural Competence Cultivating System}

With the economic globalization and China's economic and social development into a new era, intercultural competence becomes the new and necessary demand of the college graduates. Higher vocational colleges should put more resources and emphasis to broaden and deepen the relevant research. By optimizing the top-level design, the higher vocational colleges should design the cultivating system and the curriculum systematically and construct a platform which is suitable for cultivating the learners' international perspective and global citizen awareness. In fact, general education is the most appropriate platform for carrying out the IC cultivating [14]. On the basis of general education, the higher vocational colleges can construct an IC cultivating system.

\section{Decide the IC Teaching Objectives more Scientifically}

When deciding the intercultural competence teaching objectives, we should consider the teaching environment, the participants (the teacher, the students, other people) and the other core elements involved in as a whole system and each element in the whole system interact with and influenced by each other.

For the teaching environment, we should consider four aspects, that is, the macro teaching environment, the middle teaching environment, micro teaching environment, and the super-micro teaching environment. The macro teaching environment includes politics, economy, society and technology environment. The middle teaching environment means the mission, the function and the development of different education stages (pre-school, elementary, secondary, vocational, higher 
education, etc.). For the micro teaching environment, we should consider the resources, the development, the history, the aims, etc. of the specific school. For the super-micro teaching environment, we should consider where we conduct the teaching (classroom, campus, field work, self-learning, etc.), whether the environment can meet the demand and how to make full use of the environment.

Among the core elements, the participants are the most active and decisive when deciding the teaching objectives. The participants can be the teacher, the students and other people involved. We need to analyze the ability, characteristics and features of the participants and decide the teaching objectives.

\section{Construct a Systematic and Functional IC Cultivating System}

The IC cultivating system is the important component of general education. In order to construct the cultivating system, we should decide the domain of the courses (or activities) and clarify the relationship of the related courses and make clear of the teaching objectives, function and criterion of each course or activity. Culture can be viewed as a dynamic developing process. As an important part of general education, when we decide the domain of the course,the courses in different domains should be distributed evenly and each course should be responsible for certain teaching objectives. The courses are related but not overlapped.

\section{The Courses (or Activities) Should be Competency-based and High-impact}

When designing the courses (or activities), we should hold the idea that our aim is to cultivate the intercultural competence of the students. Thus, for the three key factors (knowledge, attitude and critical cultural awareness), we should give equal emphasis. When introducing the cultural knowledge, we should not just list cultures and cultural phenomenon, but also help the students to get a deep understanding of different cultures and values and cultivate and train the attitude and critical cultural awareness.

Meanwhile, the Courses (or Activities) should be high-impact. The High-impact theory shows that high-impact activities can influenced the learners deeply. Thus, when we design the IC cultivating system, we can design some high-impact practices, which will increase the teaching efficiency and help to achieve the teaching objective.

\section{Summary}

Intercultural competence is the demand of the changing world. To cultivate the learns' international vision and global awareness is the necessary choice for China's higher vocational education. China's higher vocational education has lots of challenges and chances in the field of cultivating intercultural competence. Thus, the higher vocational colleges should strengthen the theoretical and practical research of IC; optimize the tope-level design; construct the IC cultivating system scientifically and help the students become the international talents who can adapt to the new economic and social development.

\section{References}

[1] Information on https://en.unesco.org/world-education-forum-2015/incheon-declaration

[2] Shanghai Academy of Education and Research, Mycos, 2017 Annual Report on Higher Vocational Education in China, Higher Education Press, 2017.

[3] Craft, William(2012). Liberal Arts Beyond the Credit: Whole Person Education in a Global Age. MPCC-UIC Presidential Lecture, 14 November 2012. Zhuhai: BNU-HKBU United International College. 
[4]

Information

on

https://news.harvard.edu/gazette/story/2007/02/general-education-task-force-issues-final-report/

[5] Information on http://www.niu.edu/gened/news/index.shtml

[6] Chan A. H. P., A New General Education Reform and Its Reflections at National University of Singapore, Gan Yang, Sun Xiangchen, General Education Review, Fudan Press, 2016, pp. 165.

[7] Information on http://www.un.org/en/index.html

[8] Information on http://www.fudan.edu.cn/en/channels/view/48/

[9] Wanying Wang, The Yuanpei Program in Peking University: A Case Study of Curriculum Innovation, Springer, 2013, pp. 60.

[10] $\mathrm{Hu}$ Wenzhong, China's Intercultural Communication Viewed from the Perspective of Disciplinary Development, Journal of Foreign Languages, November 2010, Vol.33 No.6.

[11] Michael Byram, Teaching and Assessing Intercultural Communicative Competence, Shanghai Foreign Language Education Press, 2014, pp. 50-54.

[12] Sun Youzhong, Foreign Language Teaching and Intercultural Competence Cultivation, Foreign Languages in China, May 2016, Vol.13 No. 3.

Information

on

https://kns-cnki-net.vpn.bitc.edu.cn/kns/brief/Default_Result.aspx?code=CIDX\&kw=\%E8\%B7\%A 8\%E6\%96\%87\%E5\%8C\%96\%E8\%83\%BD\%E5\%8A\%9B\&korder=\&sel=1

[14] Yuan Xiling, Cui Yaping, The Enlightenment of American Experience on Intercultural Courses Construction in General Education in China, Journal of Socialist Theory Guide, June 2010, pp. 94-96. 